\title{
PENGARUH MEKANISME CORPORATE GOVERNANCE, CORPORATE SOCIAL RESPONSIBILITY, UKURAN PERUSAHAAN DAN LEVERAGE TERHADAP PENGHINDARAN PAJAK (Studi Pada Perusahaan Manufaktur yang Terdaftar di Bursa Efek Indonesia Tahun 2015-2017)
}

\author{
Afrizal Tahar ${ }^{1}$, Dewi Rachmawati ${ }^{2}$ \\ Universitas Muhammadiyah Yogyakarta ${ }^{1,2}$ \\ afrizal_pg@yahoo.com
}

\begin{abstract}
This research aimed to test the influence of Gorporate Governance Mechanisms, Corporate Social Responsibility, Firm Size and Leverage towards tax avoidance. The population in this research is manufacturing companies listed on Indonesian Stock Exchange of years 2015-2017. This study used 108 companies as the sample selected by purposive sampling method. The data for this research was collected from several sources such as annual reports and the summary of financial statement of the sample companies, obtained from the database of Indonesian Stock Exchange and www.idx.co.id. Multiple regression analysis is employed to test the hypotheses. The result show that institutional ownership, proportion of independent commisioners, audit quality, audit committee, corporate social responsibility, and leverage has positive effect on tax avoidance, while firm size has negative effect on tax avoidance.
\end{abstract}

Keywords: Corporate Governance Mechanism, Corporate Social Responsibility, Firm Size, Leverage.

\begin{abstract}
ABSTRAK
Penelitian ini dilakukan untuk menguji pengaruh Mekanisme Corporate Governance, Corporate Social Responsibility, Ukuran Perusahaan, dan Leverage terhadap Penghindaran Pajak. Populasi dalam penelitian ini adalah perusahaan manufaktur yang terdaftar di Bursa Efek Indonesia (BEI) pada tahun 2015-2017. Penelitian ini menggunakan 108 perusahaan sebagai sampel yang dipilih dengan metode purposive sampling. Data dalam penelitian ini didapat dari beberapa sumber seperti seperti laporan tahunan dan summary of financial statement perusahaan yang menjadi sampel penelitian, yang diperoleh dari database Bursa Efek Indonesia (BEI) dan www.idx.co.id. Pengujian hipotesis menggunakan analisis regresi berganda. Hasil penelitian menunjukkan bahwa kepemilikan institusional, proporsi dewan komisaris independen, kualitas audit, komite audit, tanggung jawab sosial perusahaan, dan leverage berpengaruh positif terhadap penghindaran pajak, sedangkan ukuran perusahaan berpengaruh negatif terhadap penghindaran pajak.

Kata kunci: Corporate Governance Mechanism, Corporate Social Responsibility, Ukuran Perusahaan, Leverage.
\end{abstract}




\section{PENDAHULUAN}

Di banyak negara, termasuk di Indonesia, pajak adalah salah satu pendapatan negara yang paling besar. Kementrian Keuangan Republik Indonesia menyatakan bahwa pada tahun 2016 porsi penerimaan negara terbesar bersumber dari pajak, yakni sebesar $84,96 \%$. Sayangnya, penerimaan pajak negara Indonesia masih belum maksimal, hal ini bisa dilihat dari rata-rata tax ratio Indonesia selama lima tahun terkahir yang hanya berkisar $11 \%$, dimana angka ini berada di bawah target yang telah ditetapkan oleh pemerintah dalam Anggaran Pendapatan dan Belanja Negara (APBN) yaitu sebesar 13,11\%.

Rendahnya tingkat penerimaan pajak di Indonesia disebabkan oleh banyaknya praktik penghindaran pajak yang dilakukan oleh wajib pajak (Badertscher, dkk. 2019). Penghindaran pajak adalah salah satu cara untuk menghindari pajak secara legal yang diatur dalam Undang-Undang Perpajakan. Sari (2014) menjelaskan bahwa secara hukum penghindaran pajak tidak dilarang, walaupun sering mendapatkan tanggapan yang kurang baik. Dengan adanya praktik penghindaran pajak negara akan kehilangan penerimaan pajak dengan jumlah yang signifikan (Lolana and Dwimulyani, 2019).. Maharani dan Suardana (2014) dan Dewi dan Jati (2014) menemukan bahwa aspek corporate governance berupa kepemilikan institusional berpengaruh negatif terhadap penghindaran pajak. Hasil tersebut tidak sejalan dengan Alfajri dan Paulus (2016) dan Feranika (2016) bahwa kepemilikan institusional berpengaruh positif terhadap penghindaran pajak. Selanjutnya, Maharani dan Suardana (2014) menyatakan bahwa proporsi dewan komisaris independen berpengaruh negatif terhadap penghindaran pajak. Namun, hasil penelitian Alfajri dan Paulus (2016) serta Handayani dan Aris (2015) menunjukkan bahwa proporsi dewan komisaris independen berpengaruh positif terhadap penghindaran pajak. Kemudian, Sandy dan Lukviarman (2015), Rahmawati dkk (2016) menunjukkan bahwa kualitas audit berpengaruh negatif terhadap penghindaran pajak. Penelitian ini bertolak belakang dengan penelitian yang dilakukan oleh Handayani dan Aris (2015), Fadilah (2014) bahwa kualitas audit berpengaruh positif terhadap penghindaran pajak. Terakhir, terkait dengan komite audit, penelitian yang dilakukan Kurniasih dan Sari (2013), Sandy dan Lukviarman (2015) menunjukkan bahwa komite audit berpengaruh negatif terhadap penghindaran pajak. Sedangkan penelitian Alfajri dan Paulus (2016), Fadilah (2014) komite audit berpengaruh positif terhadap penghindaran pajak.

Selain isu corporate governance dan CSR, terdapat beberapa faktor lain yang diduga berpengaruh terhadap praktik penghindaran pajak. Diantaranya adalah ukuran perusahaan dan leverage. Kurniasih dan Sari (2013) serta Swingly dan Sukartha (2015) mengatakan bahwa ukuran perusahaan berpengaruh negatif terhadap penghindaran pajak. Tidak sejalan dengan penelitian yang dilakukan oleh Saifudin dan Yunanda (2016) yang menyatakan bahwa ukuran perusahaan berpengaruh positif terhadap penghindaran pajak. Sementara penelitian mengenai leverage, yang merupakan rasio jumlah utang yang dimiliki perusahaan untuk pembelian aset, yang dilakukan oleh Saifudin dan Yunanda (2016), Saputra dan Asyik (2017) menyatakan bahwa leverage berpengaruh positif terhadap penghindaran pajak. Kemudian ada penelitian yang bertolak belakang yaitu penelitian dari Kurniasih dan Sari (2013) yang menyatakan bahwa leverage berpengaruh negatif terhadap penghindaran pajak. 
Berdasarkan hasil penelitian sebelumnya, dapat dilihat bahwa faktor yang memiliki pengaruh terhadap penghindaran pajak diantaranya adalah aspek corporate governance, CSR, ukuran perusahaan, dan leverage. Namun, masih terdapat perbedaan pada hasil pengaruh factor-faktor tersebut terhadap penghindaran pajak. Maka dari itu penelitian ini berusaha membuktikan secara empiris mengenai pengaruh corporate governance (yang pada penelitian ini diukur dengan variabel kepemilikan institusional, proporsi dewan komisaris independen, kualitas audit dan komite audit), corporate social responsibility (CSR), ukuran perusahaan dan leverage berpengaruh terhadap penghindaran pajak yang dilakukan, dengan memperbaiki sekaligus menambah tahun pengamatan yang digunakan dalam penelitian.

\section{TINJAUAN PUSTAKA DAN PENGEMBANGAN HIPOTESIS}

\section{Teori Keagenan}

Jensen dan Meckling (1976) menyatakan bahwa hubungan keagenan adalah suatu bentuk kerjasama antara pemilik perusahaan dengan manajer (agent). Hubungan keagenan tersebut biasanya sering menimbulkan masalah antara pemilik perusahaan dan manajer atau sering disebut sebagai konflik kepentingan.Teori keagenan adalah masalah yang terjadi antara manajer dengan pemilik perusahaankarena adanya perbedaan tujuan, pemilik perusahaan menginginkan bertambahnya aset dan kemakmuran pemilik modal, sedangkan manajer menginginkan bertambahnya kesejahteraan untuk para manajer.

Keterkaitan antara teori keagenan terhadap penelitian ini adalah bahwa manajemen melakukan tindakan penghindaran pajak karena ingin memaksimalkan laba untuk mengimbangi keinginan stakeholder yaitu menghasilkan laba yang sebesar-besarnya. Selain itu, agar kinerja manajemen dapat dinilai baik dan meningkat dari tahun ke tahun. Inti dari uraian diatas bahwasannya manajemen tidak bisa terlepas dari tindakan penghindaran pajak.

\section{Teori Legitimasi}

Dowling dan Pfefer (1975) menyatakan bahwa teori legitimasi perusahaan selalu berusaha menciptakan keseimbangan antara nilai-nilai perusahaan dengan norma-norma sosial di lingkungan sosial sekitar, dimana perusahaan termasuk bagian dari lingkungan sosial tersebut. Hal seperti ini dilakukan untuk mendapatkan legitimasi dari masyarakat. Salah satu usaha untuk mendapatkan legitimasi masyarakat yaitu dengan membayar pajak sesuai dengan peraturan undang-undang yang berlaku tanpa melakukan kegiatan yang bisa merugikan banyak pihak maupun orang lain.

Ghozali dan Chairi (2007) menerangkan bahwa teori legitimasi adalah kontrak sosial dengan masyarakat dimana perusahaan beroperasi dan menggunakan sumber ekonomi. Pada teori legitimasi, perusahaan memfokuskan pada interaksi dengan para stakeholder. Hal ini penting karena perusahaan memerlukan adanya pengakuan dari investor, kreditor, konsumen, pemerintah, maupun masyarakat sekitar. Perusahaan yang sadar akan kelangsungan hidupnya akan sangat bergantung pada masyarakat dan lingkungan. Oleh karena itu, perusahaan harus 
mampu melakukan aktivitas-aktivitas yang sesuai dengan nilai-nilai keadilandan batasan norma yang berlaku di masyarakat.

Teori ini menyarankan kepada perusahaan untuk meyakinkan bahwa aktivitas dan kinerjanya dapat diterima oleh masyarakat. Perusahaan memakai laporan keuangan mereka untuk menggambarkan kesan tanggung jawab lingkungan, sehingga mereka diterima oleh masyarakat.

\section{Teori Stakeholder}

Teori ini menyatakan bahwa perusahaan beraktivitas tidak hanya untuk kepentingan pemilik perusahaan yang terkena akibat atas kegiatan perusahaan (Ghozali dan Chariri, 2007). Berdasarkan pernyataan tersebut perusahaan tidak boleh beroperasi untuk kepentingan pribadi, akan tetapi harus memberikan manfaat kepada pemilik perusahaannya seperti stakeholder, peminjam, konsumen, pemasok, pemerintah, masyarakat, dan pihak lain.

Teori stakeholder menjelaskan pentingnya penerapan CSR sebagai bentuk pertanggung jawaban kepada para stakeholder, yang diharapkan dapat meminimalisir tindakan penghindaran pajak. Hal ini dikarenakan apabila perusahaan yang menjalankan CSR bersifat agresif terhadap pajak maka dapat menyebabkan hilangnya reputasi dimata stakeholder. Teori stakeholderumumnya digunakan untuk memenuhi kepentingan semua pihak. Teori ini menunjukkan bahwa perusahaan tidak hanya memiliki tanggung jawab pada kesejahteraan perusahaannya saja, namun juga pada semua pihak, seperti pemegang saham, institusi, dan pemerintah sebagai pihak yang akan terkena dampak atas tindakan dan kebijakan strategi perusahaan (Pradipta dan Supriyadi, 2015). Apabila perusahaan mampu untuk menyeimbangkan seluruh kepentingan para stakeholder, maka perusahaan dapat dikatakan telah sukses dalam menjalankan perusahaannya. Kemudian perusahaan akan mendapatkan dukungan secara konsisten dan menikmati pertumbuhan pangsa pasar, penjualan, dan laba. Teori ini beranggapan bahwa masyarakat dan lingkungan merupakan stakeholder inti perusahaan yang harus diperhatikan.

\section{Penghindaran Pajak}

Dyreng dan Maydew (2008) menyatakan bahwa penghindaran pajak adalah segala bentuk kegiatan yang menghambat dalam pemungutan pajak yang mengakibatkan berkurangnya penerimaan kas negara. Biasanya penghindaran pajak dilakukan dengan cara memanfaatkan kelemahan-kelemahan yang ada dalam ketentuan perpajakan dan terkesan tidak melanggar hukum perpajakan. Sedangkan menurut Shafer dan Simmons (2006), penghindaran pajak adalah suatu skema transaksi yang ditujukan untuk meminimalkan beban pajak dengan memanfaatkan berbagai kelemahan ketentuan perpajakan suatu negara sehingga ahli pajak menyatakan legal karena tidak melanggar peraturan perpajakan. Dengan demikian dapat disimpulkan penghindaran pajak adalah tindakan legal atau boleh dilakukan oleh wajib pajak dengan memanfaatkan kelemahan dari Undang-undang yang berlaku untuk mengurangi beban pajak perusahaan.

Praktik penghindaran pajak sering memanfaatkan kelemahan-kelemahan dari hukum pajak dan dalam kegiatannya tidak melanggar hukum pepajakan. Untuk melihat seberapa besar perusahaan melakukan praktik penghindaran pajak yaitu 
dengan cara menilai seberapa besar perusahaan memanfaatkan kelemahan yang ada untuk melakukan penghindaran pajak. Dalam melakukan penghindaran pajak, perusahaan akan mendapatkan keuntungan dan kerugian. Keuntungan yang didapat yaitu perusahaan hanya mengeluarkan sedikit kas untuk membayar pajak sehingga jumlah kas yang dimiliki perusahaan akan tetap besar. Sedangkan kerugiannya yaitu mendapatkan sanksi dari fiskus pajak dan turunnya harga saham serta hilangnya reputasi perusahaan akibat audit.

\section{Pengaruh Kepemilikan Institusional terhadap Penghindaran Pajak}

Menurut Tarjo (2008) kepemilikan institusional adalah kepemilikan saham yang dimiliki oleh institusi seperti asuransi, bank, perusahaan investasi dan kepemilikan institusi lain. Kepemilikan institusional biasanya diukur menggunakan jumlah pemilik perusahaan oleh investor institusi terhadap total jumlah saham yang beredar (Annisa dan Kurniasih, 2012). Investor institusi adalah perusahaan lain yang mempunyai saham pada badan hukum tertentu dimana keterangannya adalah persentase saham yang dimiliki investor institusi tersebut dibandingkan dengan jumlah saham badan hukum yang beredar.

Berdasarkan teori keagenan, kepemilikan institusional dalam struktur kepemilikan memiliki peran dalam memonitoring manajemen, kepemilikan institusional merupakan pihak yang berpengaruh dalam pengambilan keputusan karena sifatnya sebagai pemilik saham mayoritas, selain itu kepemilikan institusional merupakan pihak yang memberikan kontrol terhadap manajemen dalam kebijakan keuangan perusahaan. Menurut Tarjo (2008), kepemilikan institusional adalah kepemilikan saham suatu perusahaan oleh institusi atau lembaga seperti perusahaan asuransi, bank, perusahaan investasi, dan kepemilikan institusi lainnya. Penelitian yang dilakukan oleh Shafer dan Simmons (2006) menemukan bahwa kepemilikan institusional memaikan peran penting dalam memantau, mendisiplinkan dan mempengaruhi manajer pajak. Kepemilikan institusional mempunyai arti penting dalam memonitor manajemen karena dengan adanya kepemilikan institusional maka akan mendorong peningkatan pengawasan operasional perusahaan yang lebih optimal.

Tingkat kepemilikan institusional yang tinggi akan menimbulkan usaha pengawasan yang lebih besar oleh pihak investor institusional sehingga akan menghalangi perilaku manajer yang mementingkan kepentingan pribadi yang nantinya akan merugikan pemilik perusahaan. Hal ini menunjukkan bahwa kepemilikan institusional yang tinggi dalam perusahaan akan memonitoring manajer dalam melakukan pengungkapan yang sesuai aturan pemerintah. Maka dari itu, salah satu akibat dari monitoring yang tinggi terhadap manajer adalah menghindari penghindaran pajak. Hal ini sejalan dengan hasil penelitian yang dilakukan oleh Maharani dan Suardana (2014), Sandy dan Lukviarman (2015), serta Saifudin dan Yunanda (2016) yang menyatakan bahwa kepemilikan institusional berpengaruh negatif terhadap penghindaran pajak. Berdasarkan uraian tersebut, hipotesis pertama dalam penelitian ini adalah :

H1 : Kepemilikan Institusional berpengaruh negatif terhadap penghindaran pajak. 


\section{Pengaruh Proporsi Dewan Komisaris Independen terhadap Penghindaran Pajak}

Menurut UU PT No. 40 Tahun 2007 komisaris merupakan sekelompok orang yang ditunjuk untuk melakukan tugas mengawasi secara keseluruhan sesuai dengan anggaran dasar dan memberikan saran pada direksi. Komisaris Independen adalah seseorang yang tidak mempunyai ikatan kerja sama dengan pemilik perusahaan pengendali, tidak memiliki hubungan kerja sama dengan pimpinan perusahaan atau komisaris serta tidak mempunyai jabatan sebagai direktur pada suatu perusahaan yang bersangkutan dengan perusahaan pemilik menurut peraturan yang dikeluarkan oleh BEI (Pohan 2008).

Dari perspektif teori agensi, anggota Dewan Komisaris yang berasal dari luar perusahaan (Komisaris Independen) berperan untuk mengawasi jalannya peran eksekutif yang lain. Adanya kemungkinan eksekutif yang lain melakukan kecurangan guna mempertahankan jabatan mereka sehingga merugikan pemegang saham maka pengawasan dari Komisaris Independen itu diperlukan. Boediono (2005) mengatakan bahwa dewan komisaris dalam melaksanakan fungsi pengawasan dapat mempengaruhi pihak manajemen untuk menyusun laporan keuangan yang berkualitas. Komisaris independen dapat melaksanakan fungsi monitoring untukmendukung pengelolaan perusahaan yang baik dan menjadikan laporan keuangan lebih objektif. Agusti (2014) menyatakan bahwa penghindaran pajak dapat menurunkan kredibilitas perusahaan jika tindakan tersebut diketahui oleh pihak yang berwenang. Komisaris independen yang merupakan bagian dari dewan komisaris melakukan pengawasan yang cukup baik terhadap manajemen perusahaan sehingga dapat mencegah terjadinya penghindaran pajak.

Penelitian yang dilakukan oleh Maharani dan Suardana (2014) menemukan bahwa proporsi komisaris independen berpengaruh negatif terhadap penghindaran pajak. Hal ini sejalan dengan hasil penelitian yang dilakukan oleh Sandy dan Lukviarman (2015) yaitu proporsi dewan komisaris independen berpengaruh negatif terhadap penghindaran pajak. Berdasarkan uraian tersebut, hipotesis kedua dalam penelitian ini adalah :

H2 : Proporsi Komisaris Independen berpengaruh negatif terhadap penghindaran pajak.

\section{Pengaruh Kualitas Audit terhadap Penghindaran Pajak}

Kualitas audit adalah segala kemungkinan yang dapat terjadi saat auditor mengaudit laporan keuangan klien dan menemukan pelanggaran atau kesalahan yang terjadi, dan melaporkannya dalam laporan keuangan audit (De Angelo, 1981). Audit yang berkualitas, dengan pengungkapan yang akurat atau keterbukaan adalah satu poin yang penting dalam Good Corporate Governance. Keterbukaan terhadap pemilik perusahaan dapat dicapai dengan melaporkan hal-hal yang bersangkutan dengan perpajakan pada pasar modal dan pertemuan para pemegang saham. Karena adanya anggapan bahwa implikasi dari perilaku menurunkan laba melalui perencanaan, pemegang saham tidak ingin perusahaan mereka mengambil posisi agresif dalam hal pajak dan akan mencegah tindakan tersebut jika mereka tahu sebelumnya.

Menurut Wolfensohn (1999), dalam teori keagenan, pengelolaan perusahaan harus diawasi dan dikendalikan untuk memastikan bahwa pengelolaan dilakukan 
dengan penuh kepatuhan kepada berbagai peraturan dan ketentuan yang berlaku. Setiap perusahaan yang beroperasi diwajibkan untuk melakukan pengungkapan laporan keuangan yang telah di audit. Perusahaan besar mungkin akan memiliki Kantor Akuntan Publik yang baik misalnya The Big Fouragar menghasilkan laporan audit yang baik dan terjamin. Menurut Chai dan Liu (2010), perusahaan yang mempunyai kualitas audit yang baik maka perusahaan cenderung tidak melakukan penghindaran pajak. Dengan demikian dapat disimpulkan bahwa perusahaan yang diaudit oleh KAP The Big Four tidak melakukan tindakan penghindaran pajak karena KAP The Big Four lebih bekompeten dan profesional.

Hasil penelitian yang dilakukan oleh Annisa dan Kurniasih (2012) menemukan bahwa kualitas audit berpengaruh negatif terhadap penghindaran pajak. Sejalan dengan penelitian yang dilakukan oleh Dewi dan Jati (2014) mengatakan bahwa kualitas audit berpengaruh negatif signifikan terhadap penghindaran pajak. Berdasarkan uraian di atas maka hipotesis ketiga dalam penelitian ini adalah sebagai berikut :

H3 : Kualitas Audit berpengaruh negatif terhadap penghindaran pajak.

\section{Pengaruh Komite Audit terhadap Penghindaran Pajak}

Komite Audit mempunyai peranan penting sebagai salah satu kelompok perusahaan yang harus ada dalam penerapan GCG. Pohan (2008) dalam penelitiannya menjelaskan bahwa Dewan Komisaris harus membentuk Komite Audit yang beranggotakan minimal tiga orang, diangkat dan diberhentikan serta bertanggung jawab kepada Dewan Komisaris. Tujuan pembentukan Komite Audit adalah memastikan bahwa laporan keuangan yang telah dikeluarkan tidak menjerumuskan dan sesuai dengan praktik akuntansi yang berlaku secara umum, memastikan bahwa kontrol internalnya memadai, kemudian tindak lanjut terhadap dugaan adanya penyimpangan yang material dibidang keuangan dan implikasi hukumnya, dan yang terkakhir merekomendasikan seleksi auditor eksternal.

Pohan (2008) mengartikan komite audit sebagai kelompok orang sekurangkurangnya tiga orang yang memiliki kompetensi pada bidang akuntansi dan keuangan di dalam perusahaankomite audit dalam perusahaan dipilih secara independen dan harus bersikap independen dalam perusahaan. Komite audit mempunyai peran untuk melakukan pengawasan kinerja perusahaan. Komite audit merupakan bagian dari manajer yang berpengaruh terhadap kebijakan perusahaan. Karena sebagai komite audit memliki keahlian dalam bidang akuntansi atau keuangan sehingga peran komite audit sangat penting. Apabila jumlah komite audit di dalam perusahaan banyak, maka tingkat pengawasannya tinggi. Sehingga tidak ada celah untuk melakukan penghindaran pajak. Sebaliknya, apabila jumlah komite audit sedikit, maka tingkat pengawasannya rendah. Sehingga bisa memanfaatkan celah utuk melakukan penghindaran pajak. Jadi semakin banyak jumlah komite audit maka akan mecegah penghindaran pajak. Sedangkan jika semakin sedikit jumlah komite audit maka akan meningkatkan tindakan penghindaran pajak.

Hasil penelitian yang dilakukan oleh Annisa dan Kurniasih (2012) serta Maharani dan Suardana (2014) menemukan bahwa komite audit memiliki pengaruh terhadap penghindaran pajak. Alfajri dan Paulus (2016), dan Rahmawati, dkk (2016) melakukan penelitian lebih lanjut dan menemukan bahwa komite audit 
berpengaruh negatif terhadap penghindaran pajak. Berdasarkan uraian di atas, maka hipotesis keempat dalam penelitian ini adalah sebagai berikut :

H4 : Komite Audit berpengaruh negatif terhadap penghindaran pajak.

\section{Pengaruh Corporate Social Responsibility terhadap Penghindaran Pajak}

Corporate Social Responsibility (CSR) adalah suatu konsep serta tindakan dari suatu perusahaan untuk meminimalisir adanya dampak negatif dan memaksimalkan dampak positif operasinya terhadap seluruh stakeholder dalam lingkup ekonomi, sosial dan lingkungan agar mencapai tujuan untuk pembangunan yang berkelanjutan. Menurut Lanis dan Richardson (2012), CSR merupakan kunci dalam keberhasilan dan keberlangsungan hidup perusahaan. CSR sebagai suatu komitmen keberlanjutan dalam dunia bisnis yang bertanggung jawab secara sosial, ekonomi, dan ekologi serta untuk meningkatkan kualitas lingkungan yang menjadi stakeholder perusahaan.

Ghozali dan Chairi (2007) menerangkan bahwa teori legitimasi adalah kontrak sosial dengan masyarakat dimana perusahaan beroperasi dan menggunakan sumber ekonomi. CSR atau tanggung jawab sosial perusahaan merupakan sebuah tanggung jawab perusahaan terhadap seluruh pemangku kepentingan dalam perusahaan, Bukan hanya kepada pemegang saham melainkan kepada pemerintah melalui pembayaran pajak dan masyarakat sekitar perusahaan. Jika perusahaan melakukan penghindaran pajak, artinya perusahaan tersebut tidak memenuhi tanggung jawabnya untuk berkontribusi dalam peningkatan kesejahteraan masyarakat (Freedman, 2003). Semakin tinggi tingkat pengungkapan CSR yang dilakukan perusahaan maka semakin rendah penghindaran pajaknya. Sebaliknya jika semakin rendah tingkat pengungkapan CSR yang dilakukan perusahaan maka semakin tinggi penghindaran pajaknya. Jadi apabila perusahaan mengungkapan CSR dengan benar, maka perusahaan tersebut berusaha untuk bertanggung jawab dan mematuhi aturan. Sedangkan jika perusahaan tidak benar dalam mengungkapkan CSR nya maka perusahaan tersebut tidak bertanggung jawab dan terindikasi melakukan penghindaran pajak.

Hasil penelitian yang dilakukan oleh Lanis dan Richardson (2012) mengatakan bahwa CSR berpengaruh negatif terhadap penghindaran pajak.. Didukung oleh penelitian yang dilakukan Yoehana dan Harto (2013) menyatakan bahwa CSR berpengaruh negatif terhadap penghindaran pajak. Selain itu, Purwanggono (2015) juga menyatakan bahwa CSR berpengaruh negatif terhadap penghindaran pajak. Berdasarkan uraian di atas maka hipotesis kelima dalam penelitian ini adalah sebagai berikut :

H5 : Corporate Social Responsibility berpengaruh negatif terhadap penghindaran pajak.

\section{Pengaruh Ukuran Perusahaan terhadap Penghindaran Pajak}

Ukuran perusahaan adalah suatu skala yang dapat mengklasifikasikan perusahaan dengan berbagai cara, misalnya ukuran total aset, jumlah penjualan, jumlah tenaga kerja, dan lain-lain (Suwito dan Herawaty 2012). Berdasarkan definisi tersebut maka dapat disimpulkan bahwa ukuran perusahaan adalah proksi yang menentukan besar kecilnya aset yang dimiliki oleh perusahaan. Semakin besar ukuran dari sebuah perusahaan, kecenderungan perusahaan membutuhkan dana 
akan juga lebih besar dibandingkan perusahaan yang lebih kecil, hal ini membuat perusahaan yang besar cenderung menginginkan pendapatan yang besar.

Dilihat dari perspektif teori stakeholder, perusahaan besar mempunyai jumlah stakeholder yang banyak sehingga akan mengungkapkan informasi yang luas untuk mendapatkan dukungan dari para stakeholder. Siegfried (1972), mengemukakan bahwa perusahaan yang besar akan lebih mampu mengelola sumber dayanya dalam perencanaan yang baik, sehingga semakin besar ukuran perusahaan akan semakin rendah cash effective tax ratio (CETR) nya. Selain itu, semakin besar ukuran perusahaannya, maka transaksi yang dilakukan juga semakin kompleks, hal itu memungkinkan perusahaan untuk memanfaatkan celah-celah yang ada untuk melakukan penghindaran pajak dari setiap transaksi.

Dassen (1995) menemukan bahwa semakin besar perusahaan, kualitas audit secara teknik akan semakin rendah, karena kemampuan deteksi semakin rendah. Sehingga mengakibatkan meningkatnya potensi penghindaran pajak oleh perusahaan. Hal ini sejalan dengan hasil penelitian sebelumnya yang dilakukan oleh Sari (2014) serta Saifudin dan Yunanda (2016) yang menyatakan bahwa ukuran perusahaan berpengaruh positif terhadap penghindaran pajak. Berdasarkan uraian di atas maka hipotesis keenam dalam penelitian ini adalah sebagai berikut :

H6 : Ukuran perusahaan berpengaruh positif terhadap penghindaran pajak.

\section{Pengaruh Leverage terhadap Penghindaran Pajak}

Menurut Agus (2008) leverage adalah penggunaan aset dan sumber dana (source of funds) oleh perusahaan yang memiliki biaya tetap (beban tetap) dengan maksud agar meningkatkan keuntungan potensial pemegang saham. Leverage juga dapat diartikan sebagai jumlah hutang yang dimiliki perusahaan untuk pembiayaan aset perusahaan tersebut. Besar kecilnya utang yang dimiliki perusahaan akan sangat berpengaruh terhadap besar kecilnya pajak yang dibayar. Hal ini dikarenakan adanya beban bunga atas pinjaman yang dapat mengurangi penghasilan kena pajak. Sehingga perusahaan dapat melakukan tindakan penghindaran pajak karena penghasilan kena pajak dapat berkurang karena adanya beban bunga tersebut.

Berdasarkan teori keagenan, utang adalah salah satu mekanisme bagi shareholder untuk meminimumkan masalah keagenan dengan manajer. Leverage menggambarkan hubungan antara total aset dengan modal saham biasa atau menunjukkan utang untuk meningkatkan laba (Husnan, 2002). Rasio leverage dapat digunakan untuk menggambarkan kemampuan perusahaan dalam memenuhi kewajiban jangka panjangnya. Berkurangnya sumber pendanaan di perusahaan dapat memicu konflik. Ada kemungkinan bahwa pihak principal tidak setuju dengan permintaan pendanaan dari pihak manajemen, sehingga pihak manajemen (agen) menutupi kebutuhan pembiayaan perusahaan dengan melakukan utang. Jumlah utang yang lebih banyak mengakibatkan ETR yang lebih rendah. Hal ini karena bunga dapat mengurangi pendapatan perusahaan sebelum pajak. Semakin besarnya bunga yang harus ditanggung oleh perusahaan maka akan mengakibatkan tingginya beban bunga dan beban utang perusahaan, yang berakibat pada berkurangnya jumlah beban pajak yang harus dibayarkan oleh perusahaan juga semakin kecil. Karenanya, semakin tinggi nilai leverage dalam suatu perusahaan menggambarkan perusahaan semakin tinggi pula kemungkinan dilakukannya 
tindakan penghindaran pajak. Hal ini didukung oleh penelitian sebelumnya yang dilakukan oleh Saifudin dan Yunanda (2016) yang menyatakan bahwa leverage berpengaruh positif terhadap penghindaran pajak. menyatakan leverage berpengaruh positif terhadap penghindaran pajak. Berdasarkan uraian di atas maka hipotesis terakhir dalam penelitian ini adalah sebagai berikut:

$\mathrm{H} 7$ : Leverage berpengaruh positif terhadap penghindaran pajak.

\section{Gambar 1. Model Penelitian}

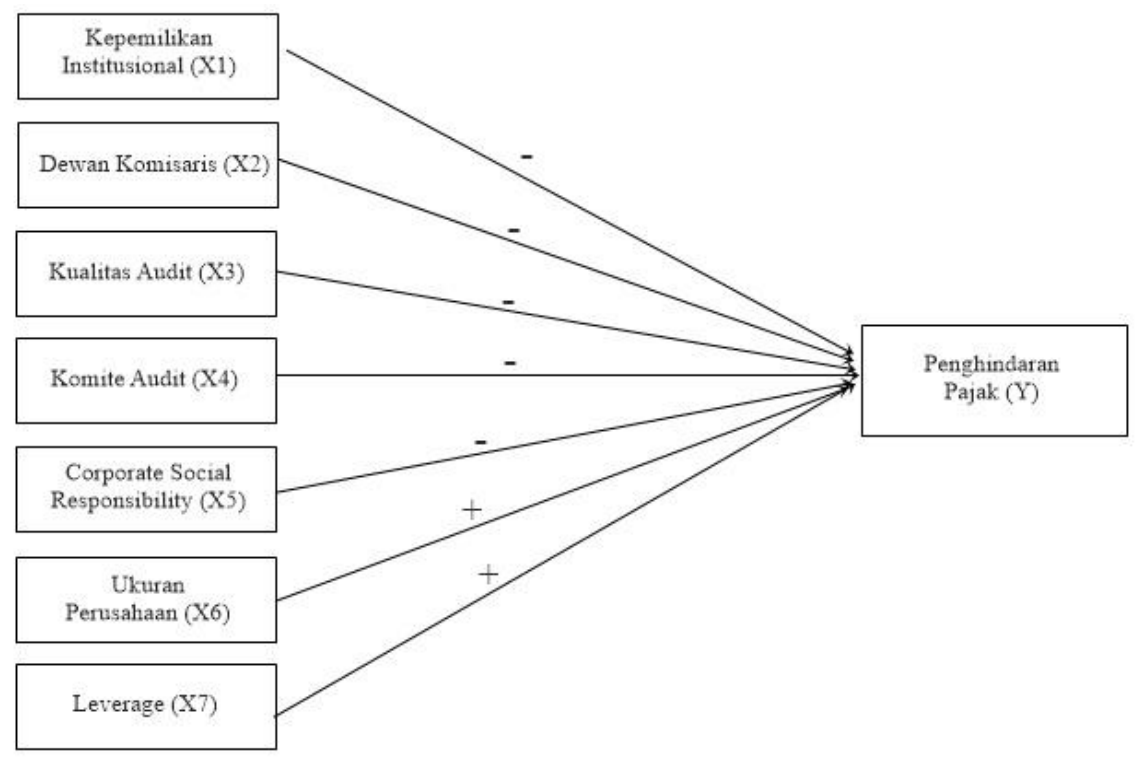

\section{METODE PENELITIAN}

\section{Sampel Penelitian}

Obyek dalam penelitian ini adalah perusahaan manufaktur, dengan sampel penelitian yaitu perusahaan manufaktur yang terdaftar di Bursa Efek Indonesia (BEI) pada tahun 2015-2017. Teknik pengambilan sampel yang digunakan adalah purposive sampling, yaitu metode penarikan sampel berdasarkan kriteria tertentu yang ditentukan oleh peneliti. Adapun kriteria yang ditetapkan sebagai berikut :

a) Perusahaan manufaktur yang terdaftar di BEI pada tahun 2015-2017.

b) Perusahaan yang memuat dan mempublikasikan laporan keuangan yang berakhir 31 Desember.

c) Laporan keuangan tahunan yang disajikan menggunakan mata uang Rupiah.

d) Perusahaan manufaktur yang tidak mengalami rugi selama penelitian pada tahun 2015-2017 secara berturut-urut.

Dalam penelitian ini, teknik pengumpulan data yang diguanakan adalah metode dokumentasi dengan cara mengumpulkan seluruh data sekunder dan seluruh informasi yang digunakan untuk menyelesaikan masalah-masalah dalam penelitian. Pengambilan data perusahaan berupa laporan keuangan pada halaman situs Bursa Efek Indonesia yaitu di www.idx.co.id. 


\section{Definisi Operasional}

\section{Variabel Dependen}

Variabel dependen dalam penelitian ini adalah penghindaran pajak. Penghindaran pajak adalah salah satu upaya penghindaran pajak yang dilakukan secara legal dengan cara mengurangi jumlah pajak terutang dengan memanfaatkan kelemahan peraturan perpajakan. Dalam penelitian ini penghindaran pajak diukur menggunakan ETR (effective tax rate) perusahaan, yaitu kas yang dikeluarkan untuk beban pajak dibagi dengan laba sebelum pajak (Budiman, 2012). Tarif pajak efektif digunakan sebagai pengukuran karena dianggap dapat menggambarkan perbedaan tetap antara laba buku dan laba fiskal.

$$
E T R=\frac{\text { Beban pajak penghasilan }}{\text { Laba sebelum pajak }}
$$

\section{Variabel Independen}

\section{Kepemilikan Institusional}

Menurut Khurana dan Moser (2009), Kepemilikan Institusional diukur menggunakan presentase jumlah saham yang dimiliki oleh institusi dari seluruh jumlah saham yang beredar. Banyak atau sedikitnya kepemilikan institusional akan mempengaruhi tindakan penghindaran pajak yang dilakukan oleh perusahaan. Kepemilikan Institusional dapat diukur dengan menggunakan rasio sebagai berikut:

$$
K I=\frac{\text { Saham yang dimiliki Institusi }}{\text { Jumlah saham yang diterbitkan }}
$$

\section{Proporsi Dewan Komisaris Independen}

Adanya variabel Proporsi Dewan Komisaris Independen dapat menunjang kinerja perusahaan dan mampu meningkatkan efektifitas monitoring. Biasanya diukur menggunakan presentase Dewan Komisaris Independen yang ada dalam suatu perusahaan. Dengan cara menjumlahkan komisaris independen kemudian dibagi dengan jumlah seluruh komisaris. Proporsi dewan komisaris independen diukur dengan rasio sebagai berikut :

$$
P K I=\frac{\text { jumlah komisaris independen }}{\text { jumlah seluruh dewan komisaris }} \times 100 \%
$$

\section{Kualitas Audit}

Kualitas audit biasanya diukur menggunakan variabel dummy dimana perusahaan yang diaudit oleh KAP The Big Four diberi angka 1 sedangkan perusahaan yang diaudit oleh KAP non The Big Four diberi angka 0. Jika perusahaan diaudit oleh KAP the Big Four, maka akan dianggap lebih berkompeten karena mampu bertahan dari tekanan manajer untuk melaporkan adanya pelanggaran (Annisa dan Kurniasih, 2012).

\section{Komite Audit}

Menurut Mayangsari (2013) kehadiran komite audit diharapkan dapat memberikan pandangan mengenai masalah-masalah yang berhubungan dengan 
kebijakan keuangan, akuntansi dan pengendalian internal. Berdasarkan Peraturan Bank di Indonesia No. 8/14/PB/2006 tentang pelaksanaan good corporate governance jumlah anggota komite audit minimal 3 orang.Komite audit diukur menggunakan variabel dummy dimana perusahaan yang memiliki komite audit diberi angka 1 dan yang tidak memiliki diberi angka 0 .

\section{Corporate Social Responsibility}

Pengukuran CSR menggunakan indikator yang ada di Global Reporting Initiative G.4 (GRI G.4) yang menggunakan metode checklist. Terdapat 91 indikator yaitu 9 indikator ekonomi, 34 indikator lingkungan, 16 indikator praktek ketenagakerjaan dan kenyamanan bekerja, 12 indikator hak asasi manusia, 11 indikator masyarakat, dan 9 indikator tanggung jawab atas produk.Selain itu pengukuran CSR yang mengungkapkan setiap indikator CSR maka diberi nilai 1 dan yang tidak mengungkapkan indikator CSR diberi nilai 0 , sehingga rumus pengungkapan CSR yaitu :

$$
C S R=\frac{\text { Item CSR Perusahaan }}{\text { Total Item Indikator GRI G.4 }}
$$

\section{Ukuran perusahaan}

Machfoedz (1994) menyatakan bahwa ukuran perusahaan adalah suatu skala yang dapat mengklasifikasikan perusahaan menjadi perusahaan besar dan kecil menurut berbagai cara seperti total aktiva atau total aset perusahaan, nilai pasar saham, rata-rata tingkat penjualan, dan jumlah penjualan.

\section{Leverage}

Leverage menunjukkan penggunaan utang untuk membiayai investasi.Leverage merupakan rasio yang mengukur seberapa jauh perusahaan menggunakan utang. Leverage menggambarkan hubungan antara total assets dengan modal saham biasa atau menunjukkan penggunaan utang untuk meningkatkan laba. Leverage diukur dengan total debt to assets ratio dengan rumus sebagai berikut :

$$
\text { Debt to Asset Ratio }=\frac{\text { Total Utang }}{\text { Total Aset }}
$$

\section{Uji Hipotesis}

Sebelum dilakukan uji hipotesis, terlebih dahulu dilakukan uji asumsi klasik yang terdiri dari uji normalitas, multikolinearitas, heteroskedastisitas dan autokorelasi. Uji hipotesis dilakukan dengan menggunakan analisis regresi berganda untuk menguji pengaruh corporate governance, corporate social responsibility, ukuran perusahaan dan leverage. Adapun persamaan regresinya yaitu :

Keterangan :

$$
T A=\alpha+\beta_{1} C G+\beta_{2} C S R+\beta_{3} U P+\beta_{4} L e v+e
$$

$\begin{array}{ll}\text { TA }(Y) & =\text { Tax Avoidance } \\ \text { CG }(X 1) & =\text { Corporate Governance } \\ \text { CSR (X2) } & =\text { Corporate Social Responsibility } \\ \text { UP }(X 3) & =\text { Ukuran Perusahaan }\end{array}$




\begin{tabular}{|c|c|}
\hline $\begin{array}{l}\text { Lev }(\mathrm{X} 4) \\
\mathrm{e} \\
\alpha \\
\beta\end{array}$ & $\begin{array}{l}=\text { Leverage } \\
=\text { Error } / \text { residual } \\
=\text { Konstanta } \\
=\text { Koefisien regresi }\end{array}$ \\
\hline
\end{tabular}

\section{HASIL PENGUJIAN HIPOTESIS}

\section{Gambaran Umum Objek Penelitian}

Sampel yang digunakan dalam penelitian ini adalah perusahaan manufaktur yang terdaftar di Bursa Efek Indonesia (BEI). Tahun yang digunakan yaitu dari tahun 2015-2017. Pemilihan tahun tersebut dimaksudkan agar lebih mencerminkan keadaan saat ini. Alasan pemilihan sampel perusahaan manufaktur karena jumlah perusahaan manufaktur sangat banyak, setiap tahunnya ada sekitar 135 perusahaan. Selain itu, perusahaan manufaktur memproduksi barang dari mulai bahan baku hingga barang jadi, sehingga peluang untuk melakukan kecurangan dalam pelaporan keuangan lebih besar dibandingkan perusahaan. Tindakan tersebut dapat dilakukan dengan memanipulasi beban perusahaan sehingga beban pajak yang harus dibayarkan perusahaan akan menurun. Teknik yang digunakan untuk penentuan sampel menggunakan purposive sampling, dimana diantara total 135 perusahaan manufaktur yang terdaftar di BEI, diperoleh 108 perusahaan manufaktur yang sesuai dengan kriteria penelitian.

\section{Hasil Uji Asumsi Klasik}

Hasil uji normalitas menggunakan uji Kolmogorov Smirnov menemukan bahwa nilai sig. sebesar $0.201>$ alpha $(0,05)$ yang berarti data berdistribusi normal. Berikutnya uji heteroskedastisitas dengan uji Glesjer menunjukkan bahwa nilai signifikansi lebih besar dari alpha 0,05 untuk seluruh variabel, maka model regresi tidak terkena heteroskedastisitas atau varians residual tersebut homogen. Selanjutnya, hasil uji multikolinearitas melalui nilai tolerance pada semua variabel independen adalah lebih dari 0,1 dan untuk nilai VIF kurang dari 10. Dengan demikian dapat disimpulkan bahwa tidak terjadi multikolinearitas di antara masingmasing variabel independen. Terakhir, dari hasil uji autokorelasi dengan menggunakan uji Durbin Watson (DW) ditemukan bahwa nilai dU sebesar 1.7637 dan nilai dW sebesar 1.784 sehingga dapat memenuhi asas $\mathrm{dU}<\mathrm{dW}<4$-dU yaitu $1.7637<1.784<2.2363$. Maka data tersebut dapat disimpulkan memenuhi kriteria dan tidak terjadi autokorelasi. Mengacu pada semua hasil uji asumsi klasik yang terpenuhi, maka pengujian hipotesis dapat dilakukan.

Table 1. Hasil Uji Hipotesis

\begin{tabular}{|c|c|c|c|c|c|}
\hline Variable & Code & Direction & Coefficient & t value & Sig. \\
\hline Kepemilikan Institusional & $\mathrm{H}_{1}$ & + & -005 &,- 149 & 882 \\
\hline $\begin{array}{l}\text { Proporsi Dewan Komisaris } \\
\text { Independen }\end{array}$ & $\mathrm{H}_{2}$ & + &,- 050 & $-1,039$ & ,301 \\
\hline Kualitas Audit & $\mathrm{H}_{3}$ & + & 025 &, 820 & ,414 \\
\hline Komite Audit & $\mathrm{H}_{4}$ & + &, 048 & 1,564 &, 121 \\
\hline CSR & $\mathrm{H}_{5}$ & + & 071 & 1,294 & 199 \\
\hline
\end{tabular}




\begin{tabular}{lllllll} 
Ukuran Perusahaan & & $\mathrm{H}_{6}$ & - &,- 005 & $-1,261$ &, 210 \\
Leverage & & $\mathrm{H}_{7}$ & + &, 127 & 3,431 &, 001 \\
\hline $\begin{array}{l}\text { Dependent } \\
\text { Avoidance }\end{array}$ & Variable: & Tax & & & & \\
\hline
\end{tabular}

Sumber: Output SPSS 2018

\section{Hasil Uji Hipotesis}

Tabel 1 menyajikan hasil uji hipotesis dari penelitian ini. Berdasarkan Tabel 1 dapat dilihat bahwa variabel kepemilikan institusional memiliki nilai signifikansi sebesar 0,882>0,05 dengan nilai koefisien regresi sebesar -0,005 maka H1 tidak terdukung. Berdasarkan hasil diatas dapat disimpulkan bahwa kepemilikan institusional berpengaruh positif terhadap penghindaran pajak. Variabel proporsi dewan komisaris independen memiliki nilai signifikansi sebesar 0,301>0,05 dengan nilai koefisien regresi -0,050 maka $\mathbf{H 2}$ tidak terdukung. Berdasarkan hasil diatas dapat disimpulkan bahwa proporsi dewan komisaris independen berpengaruh positif terhadap penghindaran pajak. Variabel kualitas audit memiliki nilai signifikansi sebesar 0,414>0,05 dengan nilai koefisien regresi sebesar 0,025 maka H3 tidak terdukung. Berdasarkan hasil diatas dapat disimpulkan bahwa kualitas audit berpengaruh posistif terhadap penghindaran pajak.

Berikutnya, variabel komite audit memiliki nilai signifikansi sebesar 0,121 > 0,05 dengan nilai koefisien regresi sebesar 0,048 maka H4 tidak terdukung. Berdasarkan hasil diatas dapat disimpulkan bahwa komite audit berpengaruh positif terhadap penghindaran pajak. Variabel CSR memiliki nilai siginifikansi sebesar 0,199>0,05 dengan nilai koefisien regresi sebesar 0,071 maka H5 tidak terdukung. Berdasarkan hasil diatas dapat disimpulkan bahwa CSR berpengaruh positif terhadap penghindaran pajak. Variabel ukuran perusahaan memiliki nilai signifikansi sebesar 0,210>0,05 dengan nilai koefisien regresi sebesar -0,005 maka H6 tidak terdukung. Berdasarkan hasil diatas dapat disimpulkan bahwa ukuran perusahaan berpengaruh negatif terhadap penghindaran pajak. Terakhir, variabel leverage memiliki nilai signifikansi sebesar 0,001 <0,05 dengan nilai koefisien regresi sebesar 0,127 maka $\mathbf{H 7}$ terdukung. Berdasarkan hasil diatas dapat disimpulkan bahwa leverage berpengaruh positif terhadap penghindaran pajak.

\section{KESIMPULAN, KETERBATASAN DAN SARAN}

Penelitian dilakukan untuk mengetahui mengenai pengaruh Kepemilikan Institusional, Proporsi Dewan Komisaris Independen, Kualitas Audit, Komite Audit, CSR, Ukuran Perusahaan, dan Leverage terhadap penghindaran pajak pada perusahaan manufaktur yang terdaftar di BEI. Merujuk pada hasil dari penelitian yang telah dilaksanakan dan mengolah data yang didapat menunjukkan bahwa hanya satu hipotesis yang terdukung, yaitu hipotesis yang menyatakan bahwa leverage berpengaruh positif terhadap penghindaran pajak. Hasil penelitian ini sejalan dengan penelitian Saifudin dan Yunanda (2016) dan Saputra dan Asyik (2017) yang menyatakan bahwa leverage berpengaruh positif terhadap penghindaran pajak.

Leverage merupakan rasio yang mengukur seberapa jauh perusahaan menggunakan hutang dalam pembiayaan. Leverage juga menggambarkan hubungan antara total aset dengan modal saham biasa atau menunjukkan 
penggunaan hutang untuk meningkatkan laba. Alasan leverage berpengaruh positif terhadap penghindaran pajak yaitu karena suatu perusahaan yang memiliki nilai leverage tinggi maka pendanaan hutang yang digunakan prusahaan juga semakin tinggi. Dengan adanya jumlah hutang maka akan menyebabkan munculnya beban bunga yang harus ditanggung oleh perusahaan. Beban bunga yang timbul akan mengurangi jumlah beban pajak perusahaan. Perusahaan yang memiliki hutang yang besar maka beban hutang yang harus ditanggung juga semakin besar. Beban hutang yang tinggi akan memberikan dampak menurunnya jumlah beban pajak yang harus dibayarkan. Menurunnya jumlah beban pajak memberikan celah untuk melakukan penghindaran pajak. Dengan demikian, semakin tinggi rasio leverage maka akan meningkatkan tindakan penghindaran pajak.

Terdapat beberapa keterbatasan pada penelitian ini, diantaranya adalah jangka waktu periode pengamatan hanya tiga tahun dari 2015-2017 sehingga sampel yang digunakan sangat terbatas, selain itu, keterbatasan sampel juga disebabkan karena obyek yang hanya menggunakan perusahaan di sektor manufaktur, sehingga hanya 108 sampel perusahaan yang dapat digunakan untuk penelitian, karena data lainnya tidak memenuhi kriteria. Obyek penelitian yang hanya menggunakan perusahaan manufaktur juga menyebabkan hasil penelitian ini tidak digunakan untuk menggeneralisasi seluruh sektor industri karena setiap sektor industri memiliki karakter yang berbeda.

Berdasarkan hasil penelitian dan keterbatasan yang ada, maka saran dari peneliti untuk penelitian selanjutnya adalah sebaiknya penelitian selanjutnya menggunakan periode jangka waktu yang lebih panjang dalam mengukur aktivitas penghindaran pajak. Selain itu, penelitian ini hanya dilakukan pada perusahaan manufaktur saja. Sehingga diharapkan peneliti selanjutnya dapat melakukan penelitian pada perusahaan lain yang juga memiliki penghindaran pajak yang tinggi yang terdaftar di BEI. Terakhir, peneliti selanjutnya diharapkan dapat menambah variabel yang belum terdapat dalam penelitian ini seperti ROA, kompensasi rugi laba, profitabilitas dan lain-lain.

\section{REFERENCES}

Agus, S. (2002). Manajemen Keuangan: Teori dan Aplikasi, edisi keempat, cetakan pertama, penerbit: BPFE.

Agusti, W. Y. (2014). Pengaruh Profitabilitas, Leverage, Dan Corporate Governance Terhadap Tax Avoidance (Studi Empiris Pada Perusahaan Manufaktur yang Terdaftar di BEI tahun 2009-2012). Jurnal Akuntansi, 2(3).

Alfajri, A., \& Paulus, S. (2016). Pengaruh Profitabilitas, Proporsi Dewan Komisaris, Komite Audit, dan Karakter Eksekutif terhadap Penghindaran Pajak (Tax Avoidance) pada Perusahaan Property yang Terdaftar di Bei Periode 2010-2013. Jurnal Online Mahasiswa Fakultas Ekonomi Universitas Riau, 3(1), 1094-1107.

Annisa, N. A., \& Kurniasih, L. (2012). Pengaruh corporate governance terhadap Tax avoidance. Jurnal Akuntansi \& Auditing, 8(2), 95-189. 
Badertscher, B. A., Katz, S. P., Rego, S. O., \& Wilson, R. J. (2019). Conforming tax avoidance and capital market pressure. The Accounting Review, 94(6), $1-30$.

Boediono, G. S. (2005). Kualitas laba: Studi pengaruh mekanisme corporate governance dan dampak manajemen laba dengan menggunakan analisis jalur. Simposium Nasional Akuntansi VIII, 172.

Budiman, J. (2012). Pengaruh Karakter Eksekutif terhadap Penghindaran Pajak (Tax Avoidance) (Doctoral dissertation, Universitas Gadjah Mada).

Cai, H., \& Liu, Q. (2009). Competition and corporate tax avoidance: Evidence from Chinese industrial firms. The Economic Journal, 119(537), 764-795.

Dassen, R. J. (1995). Audit quality: an empirical study of the attributes and determinants of audit quality perceptions (Doctoral dissertation, Maastricht University).

DeAngelo, L. E. (1981). Auditor independence,'low balling', and disclosure regulation. Journal of accounting and Economics, 3(2), 113-127.

Dewi, N. N. K., \& Jati, I. K. (2014). Pengaruh karakter eksekutif, karakteristik perusahaan, dan dimensi tata kelola perusahaan yang baik pada tax avoidance di bursa efek Indonesia. E-Jurnal Akuntansi, 249-260.

Dowling, J., \& Pfeffer, J. (1975). Organizational legitimacy: Social values and organizational behavior. Pacific sociological review, 18(1), 122-136.

Dyreng, S. D., Hanlon, M., \& Maydew, E. L. (2008). Long-run corporate tax avoidance. the accounting review, 83(1), 61-82.

Fadhilah, R. (2014). Pengaruh Good Corporate Governance Terhadap Tax Avoidance (Studi Empiris Pada Perusahaan Manufaktur yang Terdaftar di BEI 2009-2011). Jurnal akuntansi, 2(1).

Feranika, A. (2016). Pengaruh Kepemilikan Institusional, Dewan Komisaris Independen, Kualitas Audit, Komite Audit, Karakter Eksekutif, Dan Leverage Terhadap Tax Avoidance (Studi Empiris Pada Perusahaan Manufaktur di Bursa Efek Indonesia dengan Tahun Pengamatan 20102014). Jurnal Akuntansi \& Keuangan Unja, 1(4).

Freedman, J. (2003). Tax and corporate responsibility. Tax Journal, 695(2), 1-4.

Ghozali, I., \& Chariri, A. (2007). Teori akuntansi. Semarang: Badan Penerbit Universitas Diponegoro.

Handayani, C. D., \& Aris, M. A. (2015). Pengaruh Return on Asset, Karakter Eksekutif, dan Dimensi Tata Kelola Perusahaan yang Baik Terhadap Tax Avoidance.

Husnan, S. (2002). Manajemen Keuangan Teori Dan Praktek. Yogyakarta: Yayasan Badan Penerbit Gajah Mada. 
Jensen, M. C., \& Meckling, W. H. (1976). Theory of the firm: Managerial behavior, agency costs and ownership structure. Journal of financial economics, 3(4), 305-360.

Khurana, I. K. \& Moser, W. J. (2009). Institusional Ownership and Tax Aggressiveves.

Kurniasih, T., \& Sari, M. M. R. (2013). Pengaruh Return on Assets, Leverage, Corporate Governance, Ukuran Perusahaan Dan Kompensasi Rugi Fiskal Pada Tax Avoidance. Buletin Studi Ekonomi.

Lanis, R., \& Richardson, G. (2012). Corporate social responsibility and tax aggressiveness: a test of legitimacy theory. Accounting, Auditing \& Accountability Journal, 26(1), 75-100.

Maharani, I. G. A. C., \& Suardana, K. A. (2014). Pengaruh Corporate Governance, Profitabilitas, dan Karakteristik Eksekutif pada Tax avoidance Perusahaan Manufaktur. E-jurnal Akuntansi, 525-539.

Mayangsari, S. (2003). Analisis pengaruh independensi, kualitas audit, serta mekanisme corporate governance terhadap integritas laporan keuangan. Simposium Nasional Akuntansi VI, 16-17.

Pohan, H. T. (2008). Pengaruh good corporate governance, rasio tobin'sq, perata laba terhadap penghindaran pajak pada perusahaan publik. Jurnal Informasi, Perpajakan, Akuntansi dan Keuangan Publik. Jakarta: Universitas Trisakti. The Effect of good corporate governance, ratio tobin'sq, earnings average upon tax avoidance at public companies. Journal of Information, Taxation and Financial Public.

Pradipta, D. H. Supriyadi. (2015). Pengaruh Corporate Social Responsibility (CSR), Profitabilitas, Leverage, dan Komisaris Independen Terhadap Praktik Penghindaran Pajak. Jurnal Ekonomi Dan Bisnis.

Purwanggono, E. A., \& Rohman, A. (2015). Pengaruh corporate social responsibility dan kepemilikan mayoritas terhadap agresivitas pajak (Studi empiris pada perusahaan manufaktur yang terdaftar di bursa efek indonesia tahun 2011-2013). Doctoral dissertation, Fakultas Ekonomika dan Bisnis.

Rahmawati, A., \& Agusti, R. (2016). Pengaruh Pengungkapan Corporate Social Responsibility dan Corporate Governance Terhadap Tax Avoidance (Studi Pada Perusahaan Manufaktur Yang Terdaftar Di BEI Periode 2012-2014). Jurnal Mahasiswa Perpajakan, 10(1).

Saifudin, S., \& Yunanda, D. (2016). Determinasi Return on Asset, Leverage, Ukuran Perusahaan, Kompensasi Rugi Fiskal dan Kepemilikan Institusi Terhadap Penghindaran Pajak. Wiga: Jurnal Penelitian Ilmu Ekonomi, 6(2), 131-142.

Sandy, S., \& Lukviarman, N. (2015). Pengaruh corporate governance terhadap tax avoidance: Studi empiris pada perusahaan manufaktur. Islamic University of Indonesia. 
Saputra, M. D. R., \& Asyik, N. F. (2017). Pengaruh profitabilitas, leverage dan corporate governance terhadap tax avoidance. Jurnal Ilmu dan Riset Akuntansi, 6(8), 1-19.

Sari, G. M. (2014). Pengaruh Corporate Governance, Ukuran Perusahaan, Kompensasi Rugi Fiskal dan Struktur Kepemilikan terhadap Tax Avoidance (Studi Empiris Pada Perusahaan Manufaktur yang Terdaftar di BEI tahun 2008-2012). Jurnal Akuntansi, 2(3).

Shafer, W. E., \& Simmons, R. S. (2006). Social responsibility, machiavellianism and tax avoidance: A Study of Hong Kong tax professionals. Monash $U$. Department of Business Law \& Taxation Research Paper, (6).

Suwito, E., \& Herawaty, A. (2012). Analisis pengaruh karakteristik perusahaan terhadap tindakan perataan laba yang dilakukan oleh perusahaan yang terdaftar di Bursa Efek Jakarta.

Swingly, C., \& Sukartha, I. M. (2015). Pengaruh Karakter Eksekutif, Komite Audit, Ukuran Perusahaan, Leverage dan Sales Growth Pada Tax Avoidance. EJurnal Akuntansi, 47-62.

Tarjo. (2008). Pengaruh Konsentrasi Kepemilikan Institusional dan Leverage Terhadap Manajemen Laba, Nilai Pemegang Saham serta Cost of Equity Capital. Simposium Nasional Akuntansi XI. Pontianak.

Wolfensohn, J. (1999). Corporate governance is about promoting corporate fairness, transparency and accountability. Financial Times, 21.

Yoehana, M., \& Harto, P. (2013). Analisis Pengaruh Corporate Social Responsibility Terhadap Agresivitas Pajak (Studi Empiris pada Perusahaan Manufaktur yang Terdaftar di Bursa Efek Indonesia Tahun 2010-2011). Doctoral dissertation, Fakultas Ekonomika dan Bisnis. 